\title{
STUDI NETNOGRAFI PENERAPAN SKENARIO KEBIJAKAN KERUANGAN COVID-19 DI KOTA SURABAYA
}

\author{
Bagus Fadhilah Apriadi ${ }^{1}$, Talitha Aurellia Alfiansyah ${ }^{2}$, Zulfati Nur Izzah ${ }^{3}$, Risca Tasya \\ Qorina $^{4}$, Ade Tri Kencana ${ }^{5}$, Karina Pradinie Tucunan ${ }^{6}$ \\ 1,2,3,4,5,6 Departemen Perencanaan Wilayah dan Kota, Institut Teknologi Sepuluh Nopember \\ 1bagusfa09@gmail.com \\ ${ }^{2}$ tasya14042000@gmail.com \\ ${ }^{3}$ znizzah@gmail.com \\ ${ }^{4}$ riscatasyaqorina17@gmail.com \\ ${ }^{5}$ hellstormv@gmail.com \\ ${ }^{6} \mathrm{kp}$. tucunan@gmail.com
}

\begin{abstract}
The COVID-19 pandemic in Indonesia has disrupted various community activities. Likewise in Surabaya, which was identified as a black zone in 2020. Therefore, a lockdown policy has been implemented to reduce the COVID-19's spread such as PSBB Surabaya Raya I, II, and III; PPKM Surabaya; and PPKM Mikro Surabaya. The implementation of the lockdown has become trend on social media and created various assumptions. In addition, the spatial zoning regulations have not supported the pandemic so that the regulations are more siding of the economy and city development without reviewing its readiness facing the pandemic. This study uses secondary data collection methods through data mining also primary data through teleconference and distributing online questionnaires. So, from collecting data on social media and community aspirations, it is hoped that they can create spatial policies that are in accordance with community conditions and can also reduce the number of COVID-19 cases. The result shows that there are five topics becoming peoples' perceptions and preferences, such as social, economy, mobility, environment, and health. Moreover, they state that PSBB Surabaya Jilid 1,2, and 3 aren't the best policy and PPKM Micro are the best policy. Similar thing also experienced by 60\% informant stating that PPKM Micro is the best policy. There are also state policy suggestions regarding to policy, such as implementation of policies, restoration of education, vaccinations, incentives for health workers, duration of dine in, provision of assistance to workers, government social assistance, optimization of traditional markets, dissemination of information, and operating companies.
\end{abstract}

Keywords : pandemic, lockdown policy, e-ethnography

Abstrak - Surabaya merupakan salah satu kota yang teridentifikasi sebagai zona hitam pada Mei 2020. Oleh karena itu, kebijakan pembatasan telah diterapkan untuk menekan angka penyebaran COVID-19 seperti PSBB Surabaya Raya Jilid 1, 2, dan 3; PPKM Surabaya; serta PPKM Mikro Surabaya. Penerapan kebijakan pembatasan menjadi isu hangat di media sosial dan menimbulkan anggapan positif dan negatif. Selain itu, pada aspek keruangan, peraturan zonasi tata ruang belum menunjang urgensitas pandemi sehingga peraturannya lebih berpihak pada sektor ekonomi dan pembangunan kota tanpa meninjau kesiapan kotanya dalam menghadapi pandemi. Penelitian ini menggunakan metode pengumpulan data sekunder melalui mining data serta data primer melalui wawancara telekonferensi. Sehingga, dari pengumpulan data pada media sosial dan aspirasi masyarakat diharapkan dapat menciptakan kebijakan keruangan yang sesuai dengan kondisi masyarakat dan juga dapat menekan angka kasus COVID-19. Hasil menunjukkan bahwa terdapat lima topik yang cenderung menjadi persepsi dan preferensi para pengguna media sosial, yaitu sosial, ekonomi, mobilitas, lingkungan, dan kesehatan. Selain itu, mereka juga menyatakan bahwa PSBB Surabaya Jilid 1, 2, dan 3 merupakan kebijakan yang tidak diminati dan PPKM Mikro merupakan kebijakan yang paling diminati. Hal serupa juga dialami oleh para narasumber yang menyatakan bahwa 60\% narasumber menyatakan PPKM Mikro merupakan kebijakan paling efektif. Terdapat beberapa saran kebijakan menurut narasumber, terkait pelaksanaan kebijakan, pemulihan pendidikan, vaksinasi, insentif tenaga kesehatan, durasi makan di tempat, pemberian bantuan kepada buruh, bantuan sosial pemerintah, optimalisasi pasar tradisional, penyebaran informasi, dan perusahaan yang beroperasi.

Kata kunci : pandemi, kebijakan pembatasan, netnografi 


\section{PENDAHULUAN}

Pandemi COVID-19 di Indonesia menyebabkan perubahan perilaku masyarakat secara sosiokultural dan mengganggu aktivitas sosial dan ekonomi masyarakat perkotaan, tak terkecuali Kota Surabaya (Agus Rianto, Eka Wildanu 2020). Pada Mei 2020, Kota Surabaya teridentifikasi sebagai zona hitam yang menandakan tingginya angka penyebaran COVID-19. Berbagai kebijakan pembatasan untuk menekan angka penyebaran COVID-19 di Kota Surabaya telah dilakukan sejak 28 April 2020 hingga 14 Juni 2021, yaitu PSBB Surabaya Raya Jilid I, II, dan III, PPKM, dan PPKM Mikro. Berbagai kebijakan tersebut mengakibatkan berbagai permasalahan, seperti pengurangan pendapatan hingga pemutusan hubungan kerja yang tidak bisa dihindari (Lestari 2020).

Penerapan kebijakan pembatasan telah menjadi isu yang sering diperbincangkan di sosial media, seperti Twitter, baik masyarakat Kota Surabaya maupun beberapa daerah lain yang menjadi zona hitam. Perbincangan terkait hal ini juga menimbulkan berbagai anggapan, seperti anggapan positif dan anggapan negatif, seperti sebagian masyarakat yang menolak perpanjangan PSBB di Surabaya Raya dirasa kesulitan dalam memenuhi kebutuhan sehari-harinya. Di sisi lain, ada sebagian masyarakat yang tidak rela apabila Pemerintah Kota Surabaya menghentikan PSBB karena melihat peningkatan kasus setiap harinya (Suminar 2020). Tidak hanya memberlakukan kebijakan pembatasan, Pemerintah Kota Surabaya juga memberi himbauan kepada semua masyarakatnya untuk mencuci tangan, memakai masker, dan menjaga jarak (Melani 2021).

Sebagai alat pengendali ruang perkotaan, pemerintah menerbitkan dokumen Rencana Detail Tata Ruang untuk mengatur pola dan struktur ruang perkotaan yang diwujudkan dalam peraturan zonasi. Namun, aspek keruangan dalam peraturan zonasi tata ruang belum menunjang urgensitas pandemi dan lebih berpihak pada ekonomi dan pembangunan kota tanpa meninjau kesiapannya dalam menghadapi pandemi (Tucunan 2020). Selain itu, kebijakan keruangan eksisting dirasa belum optimal dalam menekan kasus COVID-19 yang diprediksikan meningkat.

Netnografi memungkinkan peneliti untuk memperoleh jawaban yang dibutuhkan dengan menyimak obrolan yang terjadi di media sosial serta dapat menganalisis pandangan dan perilaku subyek yang diteliti sehingga dapat menjadi metode inovatif dalam mengetahui dampak yang tidak diharapkan akibat adanya COVID-19 (Bakry 2017; Turcotte-Tremblay, Gali Gali, dan Ridde 2021).

Berdasarkan fakta bahwa adanya pro dan kontra akan kebijakan eksisting, maka diperlukan penelitian mengenai modifikasi kebijakan keruangan yang sesuai dengan melibatkan para pengguna media sosial melalui studi netnografi agar kebijakan dapat dijalankan secara holistik dan berkelanjutan. Harapannya, penelitian ini dapat berkontribusi sebagai salah satu pertimbangan perumusan kebijakan pembatasan COVID-19 yang mempertimbangkan aspek keruangan.

Secara teoritis, penelitian ini dapat berkontribusi dalam ilmu perencanaan wilayah dan kota yang berhubungan dengan intervensi kebijakan pembatasan serta ilmu sosial mengenai telaah persepsi dan preferensi masyarakat mengenai kebijakan pembatasan. Secara praktis, penelitian ini dapat dijadikan pertimbangan Pemerintah Kota Surabaya dalam memodifikasi 
kebijakan pembatasan berdasarkan preferensi dan persepsi masyarakat sehingga dapat mengurangi angka penyebaran COVID-19.

\section{METODE PENELITIAN}

Penelitian ini menggunakan teknik pengumpulan data sekunder dan primer. Data sekunder diperoleh dari mining data menggunakan software Octoparse, sedangkan data primer diperoleh dari wawancara telekonferensi dengan para narasumber. Metode analisis data yang digunakan adalah analisis konten untuk meninjau dan memahami persepsi dan preferensi para pengguna media sosial mengenai alternatif penerapan kebijakan pembatasan pada periode tertentu dan mengidentifikasi penerapan skenario kebijakan ruang.

\section{HASIL DAN PEMBAHASAN}

Mengetahui persepsi dan preferensi masyarakat Kota Surabaya terhadap alternatif skenario lockdown

Pada tahapan ini peneliti melakukan mining data pada media sosial Twitter untuk mendapatkan persepsi dan preferensi masyarakat. Berikut adalah data yang berhasil terkumpul.

Tabel 1. Jumlah data terkumpul per kebijakan pembatasan

\begin{tabular}{|l|l|}
\hline Nama Pembatasan & $\begin{array}{l}\text { Total } \\
\text { data }\end{array}$ \\
\hline $\begin{array}{l}\text { PSBB Surabaya Raya Jilid } \\
1,2,3\end{array}$ & 3.078 \\
\hline PPKM Surabaya & 869 \\
\hline PPKM Mikro Surabaya & 331 \\
\hline Jumlah & 4.278 \\
\hline
\end{tabular}

Setelah data terkumpul, peneliti kemudian melakukan data cleaning untuk memisahkan tweet dari hal-hal yang irelevan, seperti berita, kegiatan jual beli, dan promosi. Peneliti juga mengelompokkan tweet berdasarkan persepsi dan preferensi positif dan negatif.

Tabel 2. Jumlah data yang berhasil dibersihkan dan dikelompokkan

\begin{tabular}{|l|l|l|l|l|}
\hline Nama & \multicolumn{2}{|l|}{ Jumlah } & \multicolumn{2}{l|}{ Persentase } \\
\cline { 2 - 5 } Pembatasan & $(+)$ & $(-)$ & $(+)$ & $(-)$ \\
\hline $\begin{array}{l}\text { PSBB } \\
\text { Surabaya } \\
\text { Raya Jilid 1, } \\
\text { 2, dan 3 }\end{array}$ & 255 & 846 & 23,16 & 76,84 \\
\hline $\begin{array}{l}\text { PPKM } \\
\text { Surabaya }\end{array}$ & 18 & 14 & 56,25 & 43,75 \\
\hline $\begin{array}{l}\text { PPKM } \\
\text { Mikro } \\
\text { Surabaya }\end{array}$ & 5 & 2 & 71,43 & 28,57 \\
\hline Total & 278 & 862 & 24,39 & 75,61 \\
\hline
\end{tabular}

Tabel diatas menunjukkan bahwa persepsi dan preferensi masyarakat selama masa pembatasan didominasi dengan persepsi dan preferensi negatif sebesar $75,61 \%$ dengan tertinggi pada saat penerapan kebijakan PSBB Surabaya Jilid 1,2, dan 3 sebesar 76,84\% dan terendah pada saat PPKM Mikro Surabaya sebesar $28,57 \%$.

Selanjutnya, peneliti membedakan tweet berdasarkan topik sosial, ekonomi, mobilitas, kesehatan, dan lingkungan berdasarkan kajian literatur. 
Tabel 3. Variabel dalam masingmasing topik

\begin{tabular}{|c|c|c|}
\hline Topik & Variabel & Sumber \\
\hline \multirow[t]{2}{*}{ Sosial } & $\begin{array}{l}\text { Sentimen } \\
\text { individu }\end{array}$ & \multirow{2}{*}{$\begin{array}{l}\text { Pastor } \\
2020 ; \\
\text { Zhou } \\
\text { dkk. } \\
2021 \\
\end{array}$} \\
\hline & $\begin{array}{l}\text { Sentimen } \\
\text { kelompok }\end{array}$ & \\
\hline \multirow[t]{2}{*}{ Mobilitas } & $\begin{array}{l}\text { Mobilitas } \\
\text { internal }\end{array}$ & \multirow{2}{*}{$\begin{array}{l}\text { Herrera } \\
\text { dan } \\
\text { Godoy- } \\
\text { Faúndez } \\
2021\end{array}$} \\
\hline & $\begin{array}{l}\text { Mobilitas } \\
\text { eksternal }\end{array}$ & \\
\hline \multirow[t]{2}{*}{ Lingkungan } & Iklim & \multirow{2}{*}{$\begin{array}{l}\text { Shakoor } \\
\text { dkk. } \\
2020\end{array}$} \\
\hline & Kebersihan & \\
\hline Ekonomi & $\begin{array}{l}\text { Kondisi } \\
\text { finansial }\end{array}$ & $\begin{array}{l}\text { Brunori } \\
\text { dkk. } \\
2020 ; \\
\text { Yildirim } \\
\text { dan } \\
\text { Eslen- } \\
\text { Ziya } \\
2021\end{array}$ \\
\hline \multirow[t]{4}{*}{ Kesehatan } & $\begin{array}{l}\text { Tingkat } \\
\text { terjadinya } \\
\text { kasus }\end{array}$ & \multirow{4}{*}{$\begin{array}{l}\text { Berkovic } \\
\text { dkk. } \\
2020 ; \\
\text { Valdez } \\
\text { dkk. } \\
2020\end{array}$} \\
\hline & $\begin{array}{l}\text { Laju } \\
\text { penularan } \\
\text { virus }\end{array}$ & \\
\hline & $\begin{array}{l}\text { Laju } \\
\text { kesembuhan }\end{array}$ & \\
\hline & $\begin{array}{l}\text { Kondisi } \\
\text { mental }\end{array}$ & \\
\hline
\end{tabular}

Berdasarkan tabel diatas, dapat diklasifikasikan tweet sebagai berikut.
Tabel 4. Klasifikasi topik yang dibicarakan per kebijakan

\begin{tabular}{|l|l|l|l|l|}
\hline Topik & $\begin{array}{c}\text { PSBB } \\
\text { Surab } \\
\text { aya } \\
\text { Raya } \\
\text { Jilid } \\
1,2, \\
\text { dan } 3\end{array}$ & $\begin{array}{c}\text { PPK } \\
\text { Surab } \\
\text { aya }\end{array}$ & $\begin{array}{c}\text { PPK } \\
\text { M } \\
\text { Mikr } \\
\text { o } \\
\text { Surab } \\
\text { aya }\end{array}$ & $\begin{array}{l}\text { Jum } \\
\text { lah }\end{array}$ \\
\hline Sosial & 775 & 21 & 6 & 802 \\
\hline $\begin{array}{l}\text { Mobilit } \\
\text { as }\end{array}$ & 145 & 6 & 0 & 151 \\
\hline $\begin{array}{l}\text { Lingku } \\
\text { ngan }\end{array}$ & 6 & 0 & 0 & 6 \\
\hline $\begin{array}{l}\text { Ekono } \\
\text { mi }\end{array}$ & 62 & 5 & 1 & 68 \\
\hline $\begin{array}{l}\text { Kesehat } \\
\text { an }\end{array}$ & 83 & 0 & 0 & 83 \\
\hline
\end{tabular}

Didapati bahwa topik lebih bervariatif dengan dapat ditemuinya kelima topik yang sudah disebutkan di atas pada PSBB Surabaya Raya Jilid 1,2,3 dengan dominasi perbincangan oleh topik sosial (65\%). Sedangkan pada PPKM Surabaya hanya ada tweet yang membahas terkait topik ekonomi, mobilitas, sosial. Selain itu peneliti hanya bisa menemukan topik ekonomi dan sosial pada tweet membahas PPKM Mikro Surabaya. Setelah mengetahui berbagai persepsi masyarakat, peneliti berikutnya membedakan tweet berdasarkan aspek untuk mengetahui ranah persepsi dan preferensi pengguna sosial media.

Selain itu, diketahui bahwa aspek sosial dan ekonomi merupakan topik yang diperbincangkan selama periode pembatasan yang merepresentasikan isi pikiran para pengguna. Peneliti menyoroti beberapa isi pikiran pengguna yang mewakili tiap persepsi dan preferensi positif dan negatif Topik sosial

Kesadaran individu untuk menaati kebijakan yang ada (+): 
"psbb surabaya gak di perpanjang, kalian bakal nongkrong2 sesuka hati apa stay at home dulu? kok aku gak sampai hati ya buat nongkrong sembarangan, terlepas dari segala teori konspirasi soal covid, aku masih respectful sama tim medis yang bener 2 berjuang”@rhmaaw;

"PSBB telah memasuki tahap jilid ke 3. Ini menandakan belum ada penurunan kasus covid-19 di Surabaya. Apapun upaya yang dicanangkan oleh pemerintah, selalu membutuhkan turun tangan dari masyarakat untuk membantu...”@machfud_arifin

Kebijakan tidak akan efektif jika tidak diimbangi dengan kesadaran masyarakat (-):

"PPKM apaan, Surabaya cuma banyakin jejeran pasang road barrier dimana bikin bingung orang lewat aja. Apa gunanya? Tidak ada halangan apapun tuh kerumunan dimana-mana. Pasar malam pasar siang pasar kue semua kerumunan. Surabaya lihat saja” @mTil_Zeus

"Jumat udah mulai libur lebaran. Belum tau jadwalnya sampai kapan. Apa sekalian digandeng libur kenaikan kelas. Masuk sekolah kapan? Entahlah kapan. PSBB surabaya sampai kapan berlakunya juga ga tau. Ngeliat orang2 kayak gini ga bakal selesai dlm waktu dekat \#COVID19indonesia"

@agstnvirdi

Topik ekonomi

Berhemat (+)

"hari ini aku Alhamdulilah lagi hepi bertdey..tapi surabaya lagi psbb dan aku bersyukur karena ga jadi traktir teman teman,karena aku lagi gaada duit. ucap rasa terima kasih pada psbb" @YoungBuun

Membangkitkan ekonomi kota (+):

"PSBB jilid 4 ala Surabaya!.Pariwisata Surabaya Bangkit Bersama. Ya Surabaya akan menjalankan PSBB jilid 4. Namun
PSBB kali ini berbeda. Ya mereka mencanangkan Pariwisata Bangkit ! Sudah cukup rasanya 3..." @wargasuroboyo

" $i$ believe that the reason why positive cases are still raising in Greater Surabaya Area is that the tests are held massively and the government tried hardly to implement contact tracing. Although it is risky to end 'psbb' but it is needed to revive the economic sector"@anakrantausby

Kebijakan menyebabkan PHK (-):

"Kudu piye maneh,wes g gajian,g Ono bantuan,wes di rumahkan,nasip karyawan,\#PSBBsurabaya"@ArdanaR ajendra

"Kliennya banyak yg di Surabaya, pengusaha kuliner dan kopishop. saat kuruna, banyak usaha jatuh. Orang banyak di PHK, surabaya psbb, usaha kuliner byk yg goyah.. Orderan lukis watercolor dr luar negeri masih jalan.. Bayaran dollar, pdhl kalo kata orang halah cuma splash gitu” @adm_muralsby

"PSBB Surabaya harus sgr dihentikan, warga sdh tdk ada uang \& PHK dimana2”@budimanlb

Topik lingkungan

Polusi suara berkurang (+):

"tahun baru rasa PSBB mantap warga Surabaya.. patuh peraturan, tidurku nyenyak gaada suara knalpot brong" @ tyasswift07

Munculnya edukasi yang berhubungan dengan lingkungan $(+)$ :

"Semoga walikota baru, punya gebrakan revolusioner mengenai transportasi massal. Jangan cuma taman dibagusin, tapi surabaya tetep panas. Korelasinya saat puncak psbb, suhu udaha turun. Artinya kendaraan faktor penyumbang penyebab panas" @ AndiRazgriz

"Dapat diamati di kota besar terutama area Jakarta dan Surabaya relative rona-nya tidak mengalami perubahan 
yang signifikan selama masa PSBB." @PTPSW_BPPT

Peningkatan suhu (-): (a) "Surabaya PSBB Surabaya Panas" $@$ triyogapratamap

Topik mobilitas

Pembatasan mobilitas internal dan eksternal yang diperketat (+):

"Gerakan stay at home udah di gaungkan dari 3 bulan lalu, PSBB di Surabaya udah jilid 3, social distancing juga udah di jalankan dimana mana. Semua jalan kecil di tutup, akses masuk Surabaya di jaga ketat, penjagaan setiap RT ketat agar tdk ada org lain masuk selain warga RT tsb”@Babydwarf_

Kebijakan menyebabkan jalanan longgar atau tidak macet $(+)$ :

"saya ikut senang bapak..tidak hanya di jakarta di surabaya saja jalan protokol sudah dikosongkan karena PPKM, tenang bagian tim survey gak liat jalan jalan kecil di sampingnya yang notabene sebagai jalur buangan haha..yg penting jalur utama longgar dan sukses besar..hahahah" @OktaNarizawa

Kebijakan yang kurang efektif akibat kelalaian petugas (-):

"Wajar si kalau pasien yang positif di surabaya dan jatim semakin banyak, barusan sy lewat salah satu posko check point PSBB. Tp tak terlihat petugas yang check pengendara, yang ada malah karaokean.\#psbbsurabaya\#psbbgresik\# TerserahIndonesia”- @hutama_yulian Kebijakan yang diterapkan kurang efektif menyebabkan keramaian (-):

"PSBB Surabaya-Sidoarjo hari pertama ancurrr. Malah macet total di beberapa titik. Sing WFH can't relate xixixi”@alfianfadli

"PSBB Surabaya dan sekitarnya ga perlu diperpanjang. Ga ngaruh rasanta. Banyak checkpoint yang loss, banyak orang berkeliaran tanpa alasan jelas bahkan tanpa masker, kebijakan pemerintah juga ga jelas dan ga tegas. Mending normal lagi tapi protokol kesehatan tetap ketat. \#IMO" @ rahadyan9990

Topik kesehatan

Optimis terhadap berkurangnya laju penularan virus $(+)$ :

"Peningkatan kasus positif di surabaya khusunya adalah krn bekerjanya pemkot yang bagus yaitu getol nya melakukan test test rapid dan swab, bagus menurut saya semakin jelas klasternya dmn saja, sehingga cepet menurun grafik penyebarannya ke depan, jd tidak perlu ada PSBB jilid 3" @ febrianh12

"\#psbbsurabaya moga bisa mengurangi orang yang terkena covid 19" @ Mahboeb5

Dukungan untuk pemerintah dalam mengurangi kasus $(+)$

"Lha ini bener kasih infonya, jgn hanya pertambahan kasusnya tanpa ada penjelasan kenapa (diluar memang longgarnya psbb surabaya), maju terus bu temukan semua yg positif dan karantinakan, bubarkan yg kumpul2 apapun bentuknya” @malang_asli

"Peningkatan kasus positif di surabaya khusunya adalah krn bekerjanya pemkot yang bagus yaitu getol nya melakukan test test rapid dan swab, bagus menurut saya semakin jelas klasternya dmn saja, sehingga cepet menurun grafik penyebarannya ke depan, jd tidak perlu ada PSBB jilid 3" @ febrianh12

Peningkatan kesadaran adanya virus (+): "PSBB di Surabaya \& sekitarnya resmi berakhir, tapi masih tetep was-was mau aktifitas normal keluar rumah ngeliat penambahan kasus positif baru yang masih tinggi banget ini. Takut bawa virus ke rumah dan nularin anak istri."@arichristyanto

Membuat bosan (-): 
"surabaya kalo psbb lagi gue mau meninggoy aja dah fuagh." @arctikmonyek;

"yaowoh jgn sampe surabaya psbb lagi, pusing”@geminitrashed

"PSBB Surabaya Raya masuk jilid 3 (nyaingi sinetron Tersanjung). opo ndak mesisan PSBB sak Jatim ae $B u$ ”@Netizen_NUJatim

Tingkat terjadinya kasus tinggi (-): "Lebih baik dibuat PSBB Transisi. Yang diinginkan warga Surabaya kan kelonggaran. Tapi kalau ditiadakan langsung yang puncaknya masih tinggi bisa melonjakdrastic”@yonpurba

"Ingat selama PSBB surabaya malah naik angkanya. yang pusing bukan cuma dokter, petugas posko di balai kota surabaya juga pusing. Kalau perlu aja keluarrumah”@roy_orchestra "tingkat kesembuhan pasien naik trus iya kita bersyukur, alhamdulillah. tp lihat dong, tiap hari kasus positif baru $j g$ tinggi. ukuran terkendali itu $d r$ penambahan kasus bkn kesembuhan. surabaya raya perlu PSBB ketat, klo tdk kasian nakesnya berjatuhan satu2.”@erick_firman

Secara keseluruhan, topik dalam aspek pembatasan dapat disajikan dalam grafik berikut.

Berdasarkan

Tabel 4 dan tweet diatas, diketahui bahwa aspek sosial dan mobilitas merupakan hal yang sering diperbincangkan selama masa pembatasan yang berlaku.

Mengidentifikasi penerapan skenario kebijakan ruang dalam menekan penyebaran COVID-19 berdasarkan

\section{persepsi dan preferensi masyarakat Kota Surabaya}

Pada tahapan ini, peneliti melakukan wawancara kepada narasumber untuk mengetahui dampak yang dirasakan dan skenario kebijakan keruangan yang dapat diterapkan menurut persepsi dan preferensi masyarakat. Berdasarkan hasil wawancara, pendapat narasumber dapat dikategorikan menjadi beberapa aspek mengacu pada tujuan 1. Dari kelima narasumber, didapatkan topik terkait ketiga kebijakan (PSBB Surabaya Raya dan Jilid 1,2,3, PPKM, serta PPKM mikro) yang paling banyak yaitu pada aspek ekonomi dan mobilitas, serta tidak ada satu pun pembahasan terkait aspek lingkungan. Adapun topik yang didapatkan bisa dikategorikan sebagai berikut.

\section{Gambar 1. Klasifikasi topik pembahasan hasil wawancara}

Topik Pembahasan Hasil Wawancara

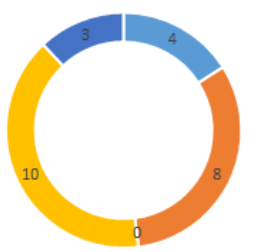

Grafik diatas menunjukkan narasumber cenderung membicarakan topik ekonomi dan mobilitas. Berdasarkan hasil temuan wawancara yang telah dikategorikan menjadi beberapa aspek, peneliti selanjutnya mengidentifikasi dampak yang dirasakan oleh para narasumber. Hasil wawancara menunjukkan bahwa 40\% narasumber menyatakan bahwa ketiga kebijakan tidak efektif karena apa yang direncanakan dan dilaksanakan tidak sesuai dan antara jumlah kasus dan kebijakan pendukung juga berbeda. Sedangkan $60 \%$ narasumber menyatakan bahwa kebijakan PPKM 
Mikro merupakan kebijakan efektif karena kebijakan ini mengendalikan lingkup RT/RW dan adanya pembatasan pergerakan dan jam kegiatan.

PPKM Mikro merupakan kebijakan yang menggantikan kebijakan PPKM akibat masih tingginya lonjakan kasus harian meski sudah terjadi penurunan yang tidak terlalu signifikan. Kebijakan ini diterapkan berdasarkan Instruksi Mendagri Nomor 3 Tahun 2021 untuk pencegahan, pembinaan, dan pemberian dukungan upaya mitigasi penyakit (Widiarto dan Alynudin 2021). Kebijakan ini mengatur hal-hal sebagai berikut.

1. Pusat perbelanjaan/mal, warung makan, restoran/rumah makan, kafe, pedagang kaki lima, lapak jajanan, toko swalayan, serta toko perdagangan barang lainnya tutup pada pukul 20.00 WIB dan bisa buka kembali pukul 05.00 WIB.

2. Layanan takeaway atau drive thru bisa dilakukan sesuai jam operasional restoran/rumah makan.

3. Menerapkan protokol kesehatan lebih ketat, pemenuhan sarana dan prasarana kesehatan untuk skrining kesehatan harian pekerja/pengunjung serta mengoptimalkan peranan satgas mandiri dalam pengawasan dan penindakan pelanggaran protokol kesehatan di tempat kegiatan.

4. Setiap orang yang bekerja/beraktivitas di Kota Surabaya yang tinggal di luar Kota Surabaya maupun sebaliknya wajib memiliki bukti cetak surat izin perjalanan atau surat izin keluar masuk (SIKM) yang diterbitkan oleh Camat tempat domisili/tinggal.

5. SIKM berlaku hingga 7 hari setelah diterbitkan.

Adapun pendapat narasumber mengenai perbaikan kebijakan PPKM Mikro yang dapat dilakukan adalah sebagai berikut.
Tabel 5. Saran kebijakan PPKM Mikro Surabaya

\begin{tabular}{|c|c|}
\hline Saran & Keterangan \\
\hline \multirow[t]{5}{*}{$\begin{array}{l}\text { Pelaksanaan } \\
\text { kebijakan }\end{array}$} & $\begin{array}{l}\text { Meninjau kondisi } \\
\text { masyarakat terdampak }\end{array}$ \\
\hline & $\begin{array}{l}\text { Meningkatkan } \\
\text { kedisiplinan aparat }\end{array}$ \\
\hline & $\begin{array}{l}\text { Menghindari kasus } \\
\text { KKN }\end{array}$ \\
\hline & $\begin{array}{l}\text { Melakukan } \\
\text { penyidikan } \\
\text { merata }\end{array}$ \\
\hline & $\begin{array}{l}\text { Meningkatkan peran } \\
\text { satuan tugas Covid-19 } \\
\text { hingga ke lingkungan } \\
\text { rumah }\end{array}$ \\
\hline \multirow[t]{2}{*}{$\begin{array}{l}\text { Pemulihan } \\
\text { pendidikan }\end{array}$} & $\begin{array}{l}\text { Meningkatkan } \\
\text { fasilitas pembelajaran }\end{array}$ \\
\hline & $\begin{array}{l}\text { Kemudahan akses } \\
\text { praktikum }\end{array}$ \\
\hline \multirow[t]{2}{*}{ Vaksinasi } & $\begin{array}{l}\text { Mempercepat } \\
\text { program vaksinasi }\end{array}$ \\
\hline & $\begin{array}{l}\text { Pencerdasan tentang } \\
\text { vaksinasi }\end{array}$ \\
\hline \multirow[t]{2}{*}{$\begin{array}{l}\text { Insentif tenaga } \\
\text { kesehatan }\end{array}$} & $\begin{array}{l}\text { Pelonggaran mobilitas } \\
\text { kepada tenaga } \\
\text { kesehatan }\end{array}$ \\
\hline & $\begin{array}{lr}\text { Pemberian } & \text { insentif } \\
\text { kepada } & \text { tenaga } \\
\text { kesehatan } & \\
\end{array}$ \\
\hline $\begin{array}{l}\text { Durasi makan } \\
\text { di tempat }\end{array}$ & $\begin{array}{l}\text { Kesadaran masyarakat } \\
\text { untuk membeli di jam } \\
\text { sepi }\end{array}$ \\
\hline $\begin{array}{l}\text { Pemberian } \\
\text { bantuan } \\
\text { kepada buruh }\end{array}$ & $\begin{array}{lr}\text { Perbaikan } & \text { sistem } \\
\text { distribusi } & \text { bantuan } \\
\text { secara efisien } & \\
\end{array}$ \\
\hline $\begin{array}{l}\text { Bantuan sosial } \\
\text { pemerintah }\end{array}$ & $\begin{array}{l}\text { Melakukan } \\
\text { penyortiran calon } \\
\text { penerima bantuan }\end{array}$ \\
\hline $\begin{array}{l}\text { Optimalisasi } \\
\text { pasar } \\
\text { tradisional }\end{array}$ & $\begin{array}{l}\text { Menggunakan layanan } \\
\text { pesan antar untuk } \\
\text { menghindari } \\
\text { keramaian }\end{array}$ \\
\hline $\begin{array}{l}\text { Penyebaran } \\
\text { informasi }\end{array}$ & $\begin{array}{l}\text { Menghindari dan } \\
\text { meminimalisasi hoax }\end{array}$ \\
\hline $\begin{array}{l}\text { Perusahaan } \\
\text { yang }\end{array}$ & $\begin{array}{lr}\text { Menindak } & \text { dan } \\
\text { memberikan } & \text { sanksi } \\
\end{array}$ \\
\hline
\end{tabular}




\begin{tabular}{|l|l|}
\hline Saran & Keterangan \\
\hline beroperasi & kepada perusahaan \\
& mempekerjakan \\
& karyawannya dengan \\
& ketentuan ada \\
& kontribusi pemerintah \\
& kepada perusahaan \\
\hline
\end{tabular}

Berdasarkan tabel diatas, maka dapat diketahui bahwa terdapat beberapa saran kebijakan yang dapat diterapkan dan menjadi bahan pertimbangan pemerintah dalam perumusan skenario kebijakan keruangan.

\section{KESIMPULAN DAN SARAN}

Berdasarkan hasil dan pembahasan penelitian, dapat ditarik beberapa kesimpulan sebagai berikut.

1. PSBB Surabaya Jilid 1,2, dan 3 merupakan kebijakan yang paling tidak diminati daripada dua kebijakan lainnya. Hal ini terbukti dari $76,84 \%$ pengguna media sosial berpersepsi negatif terhadap kebijakan tersebut serta didukung dari tidak adanya narasumber yang tidak memilih kebijakan ini sebagai kebijakan paling efektif.

2. Kebijakan PPKM Mikro Surabaya merupakan kebijakan yang paling diminati dan termasuk kebijakan yang dianggap paling efektif daripada dua kebijakan lainnya. Hal ini terlihat dari $71,43 \%$ pengguna media sosial yang berpersepsi positif terhadap kebijakan serta didukung oleh $60 \%$ narasumber yang menyatakan kesetujuannya terhadap penerapan kebijakan ini.

3. Penelitian lanjutan dapat dilakukan untuk mengidentifikasi keefektifan saran kebijakan menggunakan metode analisis yang relevan.

\section{DAFTAR PUSTAKA}

Agus Rianto, Eka Wildanu, Dikhorir Afnan. 2020. "Upaya
Masyarakat Pedesaan Melawan Covid-19 Ditinjau dari Aspek Sosiologis." Jurnal Soshum Insentif 3(2):180-87.

Bakry, Umar Suryadi. 2017. "Pemanfaatan Metode Etnografi dan Netnografi Dalam Penelitian Hubungan Internasional." Jurnal Global \& Strategis 11(1):15.

Berkovic, Danielle, Ilana N. Ackerman, Andrew M. Briggs, dan Darshini Ayton. 2020. "Tweets by people with arthritis during the COVID19 pandemic: Content and sentiment analysis." Journal of Medical Internet Research 22(12):1-17.

Brunori, Paolo, Maria Luisa Maitino, Irpet Letizia, Ravagli Irpet, dan Nicola Sciclone Irpet. 2020. "Distant and Unequal. Lockdown and Inequalities in Italy $1 . "$

Herrera, Mauricio, dan Alex GodoyFaúndez. 2021. "Exploring the roles of local mobility patterns, socioeconomic conditions, and lockdown policies in shaping the patterns of COVID-19 spread." Future Internet 13(5).

Lestari, Cindy Dwi. 2020. "Pola Komunikasi Keluarga Korban Pemutusan Hubungan Kerja di Masa Pandemi Covid-19 di Surabaya." Universitas Islam Negeri Sunan Ampel Surabaya.

Melani, Agustina. 2021. "Pemkot Minta Warga Surabaya ke Luar Kota Lebih 3 Hari Jalani Tes Usap COVID-19." Liputan6. Diambil 10 Juli 2021 (https://surabaya.liputan6.com/re ad/4447078/pemkot-mintawarga-surabaya-ke-luar-kotalebih-3-hari-jalani-tes-usapcovid-19).

Pastor, Cherish Kay L. 2020. "P2: SA of Filipinos and Effects of 
Extreme Community Quarantine Due to COVID-19 Pandemic." Journal of Critical Reviews 7(7). Shakoor, Awais, Xiaoyong Chen, Taimoor Hassan Farooq, Umer Shahzad, Fatima Ashraf, Abdul Rehman, Najam e. Sahar, dan Wende Yan. 2020. "Fluctuations in environmental pollutants and air quality during the lockdown in the USA and China: two sides of COVID-19 pandemic." Air Quality, Atmosphere and Health 13(11):1335-42.

Suminar, Agustina. 2020. "Sebagian Masyarakat Setuju Jika PSBB di Surabaya Raya Tak Diperpanjang." Kelana Kota 1. Diambil 14 Februari 2021 (https://www.suarasurabaya.net/ kelanakota/2020/sebagianmasyarakat-setuju-jika-psbb-disurabaya-raya-takdiperpanjang/).

Tucunan, Karina Pradinie. 2020. Pengaruh Variabel Keruangan Pada Periode Awal Penyebaran Pandemi Covid 19 Di Kota Surabaya. Surabaya.

Turcotte-Tremblay, Anne Marie, Idriss Ali Gali Gali, dan Valéry Ridde. 2021. "The unintended consequences of COVID-19 mitigation measures matter: practical guidance for investigating them." BMC Medical Research Methodology 21(1):1-17.

Valdez, Danny, Marijn ten Thij, Krishna Bathina, Lauren A. Rutter, dan Johan Bollen. 2020. "Social media insights into US mental health during the COVID-19 pandemic: Longitudinal analysis of twitter data." Journal of Medical Internet Research 22(12).

Widiarto, Agus, dan Suhud Alynudin.
2021. "ANALISIS

FORMULASI KEBIJAKAN PENANGGULANGAN

PANDEMI COVID-19 DI

INDONESIA SESUAI UU

NOMOR 6 TAHUN 2018 TENTANG

KEKARANTINAAN

KESEHATAN.” Jurnal Ilmiah Niagara 13(1 Juni 2021):14364.

Yildirim, T. Murat, dan Hande EslenZiya. 2021. "The differential impact of COVID-19 on the work conditions of women and men academics during the lockdown." Gender, Work and Organization 28(S1):243-49.

Zhou, Jianlong, Shuiqiao Yang, Chun Xiao, dan Fang Chen. 2021. "Examination of Community Sentiment Dynamics due to COVID-19 Pandemic: A Case Study from a State in Australia." SN Computer Science 2(3). 